\title{
Multivariate analysis of trace elements in shallow groundwater in Fuchu in western Tokyo Metropolis, Japan
}

\author{
Dang Quoc Thuyet ${ }^{1,2} \cdot$ Hirotaka Saito $^{2}$ - Takeshi Saito $^{3} \cdot$ Shigeoki Moritani $^{4}$. \\ Yuji Kohgo $^{2}$ - Toshiko Komatsu ${ }^{3}$
}

Received: 2 July 2015/ Accepted: 28 December 2015/Published online: 26 March 2016

(C) Springer-Verlag Berlin Heidelberg 2016

\begin{abstract}
A rapid increase in the use of ground source heat pump (GSHP) systems for heating and cooling of buildings potentially threatens to harm shallow groundwater quality. As a necessary preliminary step toward evaluating GSHP impact on shallow groundwater quality, this study used multivariate statistical analyses to investigate characteristics of trace elements in groundwater in Fuchu city in western Tokyo Metropolis. Water samples were collected twice a month from two aquifers at 30- and 45-m depths using four observation wells for more than a year. Concentrations of 14 trace elements $(\mathrm{Li}, \mathrm{B}, \mathrm{Al}, \mathrm{Cr}$, $\mathrm{Mn}, \mathrm{Fe}, \mathrm{Ni}, \mathrm{Cu}, \mathrm{As}, \mathrm{Se}, \mathrm{Sr}, \mathrm{Cd}, \mathrm{Sb}$, and $\mathrm{Pb}$ ) and $\mathrm{Si}$ as well as oxidation-reduction potential (ORP), dissolved oxygen (DO), electrical conductivity (EC), and $\mathrm{pH}$ were measured. All elements were under the environmental water quality criteria issued by the Japanese Ministry of the Environment. No clear seasonal trends were observed in the concentrations of 15 elements in groundwater. Principal component analyses showed the element properties were
\end{abstract}

Hirotaka Saito

hiros@cc.tuat.ac.jp

1 Graduate School of Agricultural and Life Sciences, The University of Tokyo, 1-1-1 Yayoi, Bunkyo, Tokyo 113-8657, Japan

2 Graduate School of Agriculture, Tokyo University of Agriculture and Technology, 3-5-8, Saiwaicho, Fuchu, Tokyo 183-8509, Japan

3 Graduate School of Science and Engineering, Saitama University, 255 Shimo-Okubo, Sakura-ku, Saitama, 338-8570, Japan

4 Faculty of Agriculture and Life Science, Hirosaki University, 3 Bunkyo-cho, Hirosaki, Aomori 036-8561, Japan well characterized by three principal components (PC). $\mathrm{PC} 1$, which represents the more mobile trace elements in the groundwater, consisted of $\mathrm{Li}, \mathrm{B}, \mathrm{Mn}, \mathrm{Fe}, \mathrm{As}$, and $\mathrm{Si}$. $\mathrm{PC} 2$ included $\mathrm{Al}, \mathrm{Ni}, \mathrm{Cd}$, and $\mathrm{Sb}$, and represents ORPinsensitive properties. PC3 consisted of $\mathrm{Pb}, \mathrm{Cu}$, and $\mathrm{Se}$, which are less mobile in groundwater. Samples collected from the same aquifer had high similarity in distribution and variation of the trace elements. This study proposes a useful statistical platform for assessing future effects of GSHP systems on shallow groundwater quality.

Keywords Multivariate analysis - Principal component analysis · Cluster analysis - Trace elements - Groundwater quality · Ground source heat pump (GSHP)

\section{Introduction}

As a part of the effort to reduce electricity consumption and $\mathrm{CO}_{2}$ gas emission, the use of ground source heat pump (GSHP) systems for heating and cooling buildings has received a lot of attention recently as they are much more energy efficient than conventional air source heat pump systems (Komatsu 2012). Groundwater hereby is viewed not only as a water supply resource, but also as an effective heat source/sink. At the same time, there have been some concerns that groundwater quality may be deteriorated due to changes in groundwater temperature (Saito et al. 2014). Understanding the controls and characteristics of the groundwater quality in areas where GSHP will be installed is essential to ensure sustainable GSHP use and to minimize the effect on subsurface environment from potential temperature changes.

It is believed that a large city with ample groundwater, like Tokyo, has high potential for ground source heat 
usage. Groundwater in Tokyo has been one of the most important natural resources (Endo 1992). Recently, several issues on the pollution of pharmaceutical products, surfactants, and nitrogen have been reported in groundwater in Tokyo (Kuroda and Fukushi 2008; Murakami et al. 2009; Kuroda et al. 2011). On the other hand, the occurrence of trace elements in groundwater in Tokyo has still rarely been reported although this has been an issue for a long time in many Asian countries such as Vietnam (Nga 2008), Cambodia (Luu et al. 2009; Phan et al. 2013), Bangladesh, India, and China (Akai and Anawar 2013).

The chemical composition of groundwater is controlled by many factors and complex processes such as geochemical reactions, groundwater flow, and human activities, which disturb the hydrological cycle and cause groundwater pollution (Hem 1989). Each trace element behaves very differently depending upon its chemical properties, origin, and the groundwater physico-chemical characteristics. In order to understand the relationship and underlying common characteristics among trace elements, an appropriate data analysis technique is necessary. Multivariate analyses such as factor analysis and/or cluster analysis have been applied extensively to analyze groundwater quality data including major ions (Stetzenbach et al. 1999; Kim et al. 2005; Lee et al. 2008; Shyu et al. 2011) and trace elements (Stetzenbach et al. 1999; Farnham et al. 2003; Koonce et al. 2006; Chen et al. 2007). These techniques can simplify and clarify the groundwater quality data by reducing a number of variables into a small number of factors, hereby extracting meaningful information regarding the environmental aquatic chemistry. For example, Cruz and Silva (2000) found that silicate mineral dissolution was one of the main factors responsible for the chemical composition in groundwater in Pico Island, Portugal. As most studies investigate the groundwater quality only one time or twice at most, the temporal behavior of the groundwater quality has not been well studied. Chen et al. (2007) found that concentrations of V, Mn, Co, Ni, $\mathrm{Cu}, \mathrm{Ga}, \mathrm{Ge}, \mathrm{Mo}, \mathrm{Ba}, \mathrm{W}$, and $\mathrm{Pb}$ were relatively higher during the summer and lower during the winter in a coastal area of Shenzhen, China. Such temporal variation indicates that assessing at a given specific time only may lead to inaccurate information on behavior and distribution of the elements in groundwater.

In summary, there is still a lack of knowledge on concentration levels and temporal variation of trace elements in groundwater in western Tokyo. This study therefore aims to address those knowledge gaps. We focused on the behavior of trace elements in groundwater in Fuchu city, Tokyo Japan prior to the operation of GSHP systems. First, we investigated the occurrence and temporal variation of trace elements in shallow confined aquifers. Second, we used standard multivariate statistical analysis techniques such as a principal component analysis (PCA) and a hierarchical cluster analysis (HCA) to characterize the physicochemical properties of the trace elements and to demonstrate relationships among the trace elements and factors controlling the distribution of those trace elements.

\section{Materials and methods}

\section{Experimental site description}

In this study, four 50-m observation wells, namely $\mathrm{W} 1$ to W4, were installed at the campus of Tokyo University of Agriculture and Technology in Fuchu city located in western Tokyo Metropolis, Japan (Figs. 1, 2a). Groundwater in Fuchu city is known as a good water supply source for drinking water, daily life use, irrigation and local factories. The geology of the area is characterized by the Musashino Terrace, which covers the northern part of Tama River (Endo 1992) (Fig. 1). The west end of Tokyo Metropolis is the Kanto Mountains composed of pre-tertiary rocks, while to the south is the hilly Kanagawa prefecture. The elevation of Fuchu is about $30-80 \mathrm{~m}$ above the mean sea level. Groundwater in shallow confined aquifers is originated from the Kanto Mountains in Kanagawa prefecture and Tama River (Endo and Ishii 1984; Endo 1992; Imaizumi et al. 2000). Stratigraphy of the study area consists of two groups: the upper Tokyo group and the lower Kazusa group (Endo 1992). The Tokyo group consists with a 3-5-m thick Kanto loam layer (mainly volcanic ash soil) on top followed by unconsolidated layers of silt, sand, and gravel (Fig. 2b). The gravel layers function as confined aquifers throughout the terrace and the lowland. The aquifers from which groundwater has been collected in this study are therefore located in the Tokyo group. The geochemical composition and the detail soil profiles of subsurface soil layers can be seen in Fig. 2b.

The well W1 was installed in June 2011, while W2 and W3 were installed in February 2012 (Fig. 2a). The well W4 was installed more recently in August, 2012 (Fig. 2a). The wells were installed to examine the effect of operating a GSHP system on the groundwater quality in the area. Prior to operating the GSHP system, the groundwater quality was monitored for more than a year. Undisturbed soil core samples were collected from W1, W3, and W4 while drilling the wells. There are three gravel layers correspond to three main aquifers. While the first aquifer at 7-10-m depth is an unconfined aquifer, the other two at 33-m (C1) and 44-m depths (C2) in W1 or 38-m (C1) and 50-m depths $(\mathrm{C} 2)$ in $\mathrm{W} 3$, respectively, are confined aquifers as there are impermeable silt layers on top of both gravel layers (Fig. 2b). Elements in core samples were determined using X-ray florescence analysis. $\mathrm{Si}, \mathrm{Al}, \mathrm{Fe}, \mathrm{Mn}$, and $\mathrm{Ca}$ were 
Fig. 1 Topography of Musashino Terrace and Fuchu city in Tokyo

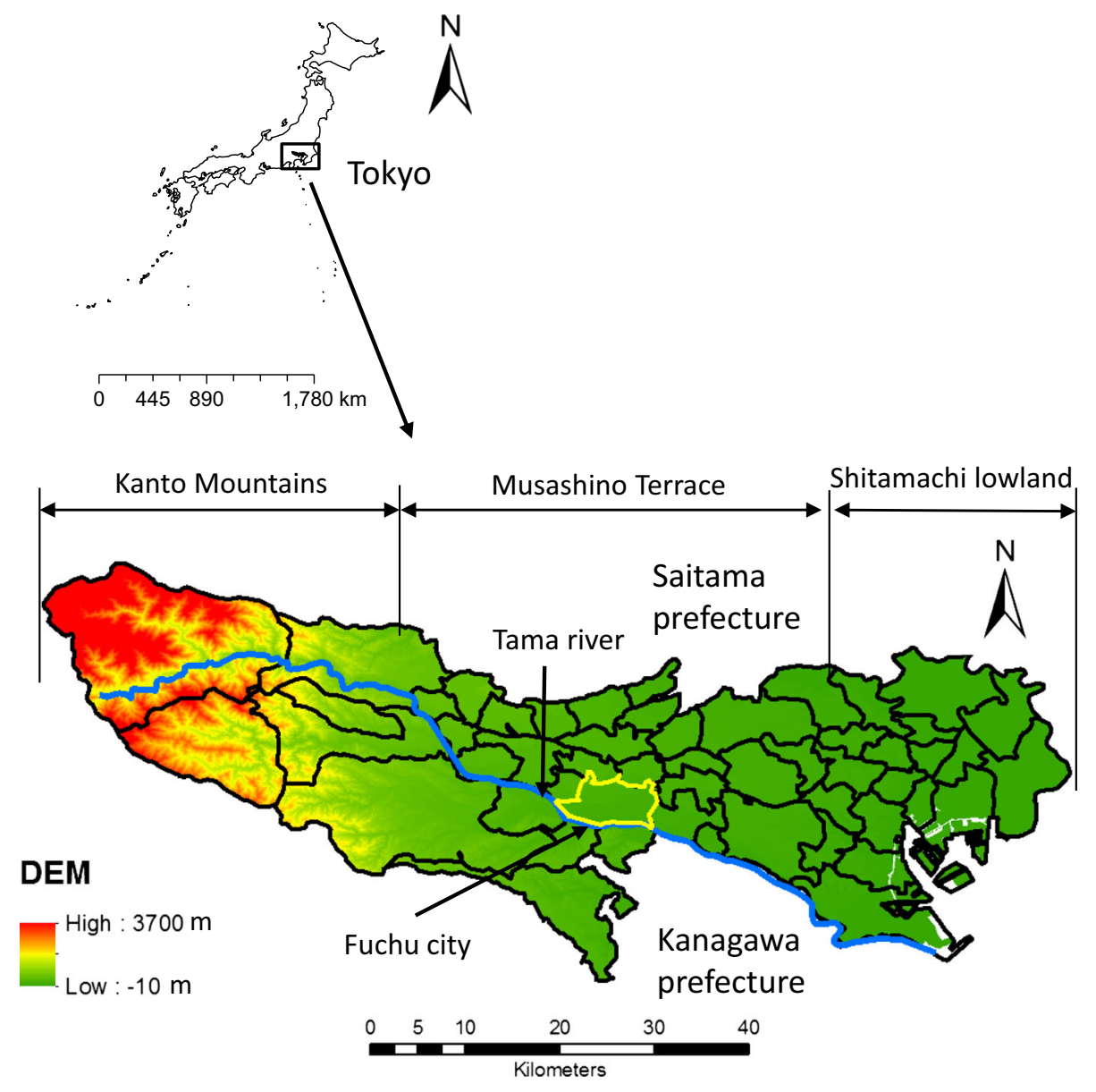

50.2, 7.8, 9.1, 0.2 and $2.4 \%$ in $\mathrm{C} 1$ core samples and 48.0, 6.2, 9.4, 0.2 and $5.0 \%$ in $\mathrm{C} 2$ core samples, respectively.

\section{Analysis of groundwater samples}

Oxidation-reduction potential (ORP), dissolved oxygen (DO), electrical conductivity (EC), $\mathrm{pH}$, and concentrations of 15 elements in the $\mathrm{C} 1$ and $\mathrm{C} 2$ aquifers were measured from groundwater samples collected from each observation well. To isolate each aquifer inside each observation well, inflatable rubber packers were installed as shown in Fig. 2b. A constant air pressure of $0.7 \mathrm{MPa}$ was maintained inside each packer to ensure sealing. A 1-m long screen with an aperture ratio of $30 \%$ was placed at the center of each confined aquifer (Fig. 2b). A stainless standpipe with an inner diameter of $20 \mathrm{~mm}$ was then connected all the way to the surface. Water levels and groundwater temperatures were measured every $10 \mathrm{~min}$ by placing a compact sensor (Micro Diver; Schlumberger, USA) at the depth of the screen inside the stainless standpipe. Water samples were collected from the stainless standpipe from each aquifer using a 1-m long stainless-steel bailer twice per month unless otherwise mentioned. The ORP, DO, EC and $\mathrm{pH}$ were measured immediately after water samples were collected using a portable water quality meter WQC-24 (DKK-TOA Corporation, Japan) on site. Water samples used to measure trace element concentrations were passed through a $0.2-\mu \mathrm{m}$ filter (DISMIC $^{\circledR}-25 \mathrm{cs}$; Toyo Roshi Kaisha Ltd., Japan) before storing in polyethylene bottles. Bottles were then kept at $4{ }^{\circ} \mathrm{C}$ until the analysis. The samples were acidified with $\mathrm{HNO}_{3}$ acid $(100 \mu \mathrm{l} 60 \%$ $\mathrm{HNO}_{3}$ per $5 \mathrm{ml}$ water sample) to free up ions. Concentrations of 15 elements, $\mathrm{Li}, \mathrm{B}, \mathrm{Al}, \mathrm{Cr}, \mathrm{Mn}, \mathrm{Fe}, \mathrm{Ni}, \mathrm{Cu}, \mathrm{As}, \mathrm{Se}$, $\mathrm{Sr}, \mathrm{Cd}, \mathrm{Sb}, \mathrm{Pb}$, and $\mathrm{Si}$, were determined by inductively coupled plasma mass spectrometry (ICPM-8500, Shimadzu Corporation, Japan). Prior to sampling, water in the standpipe was bailed out by the bailer at least 20 times in order to bring in fresh groundwater to the sampling well. We also examined the effect of stainless steel on elements concentrations in groundwater. Both deionized water and groundwater samples were exposed to the stainless steel for different durations of $0,1,3,5,15$ and 30 min to simulate the contact between the bailer and water samples during sampling. The results indicated that there were insignificant changes in trace element concentrations in both the deionized water samples and the groundwater samples. All 
Fig. 2 Experimental site and observation wells (W1-4) (a), lithology and water sampling positions (b) (a)

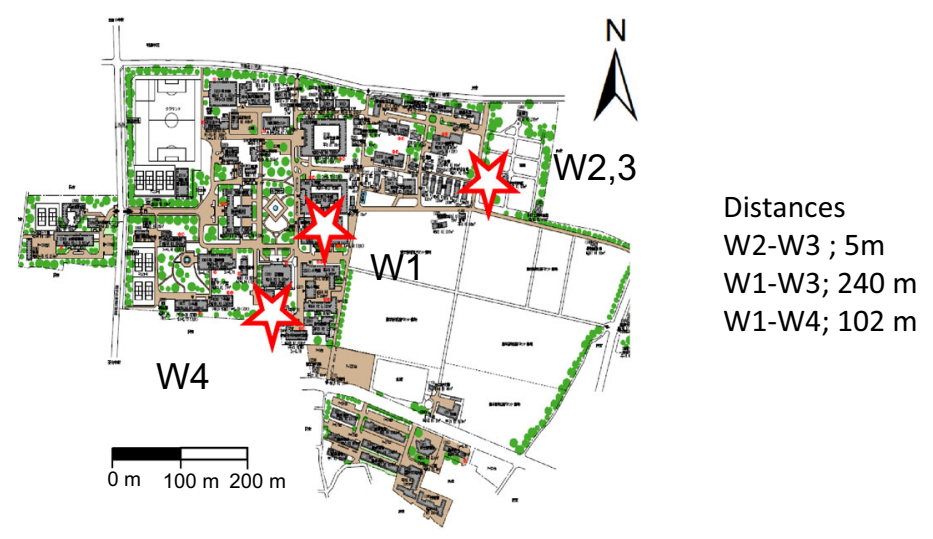

Tokyo University of Agriculture and Technology

(b)

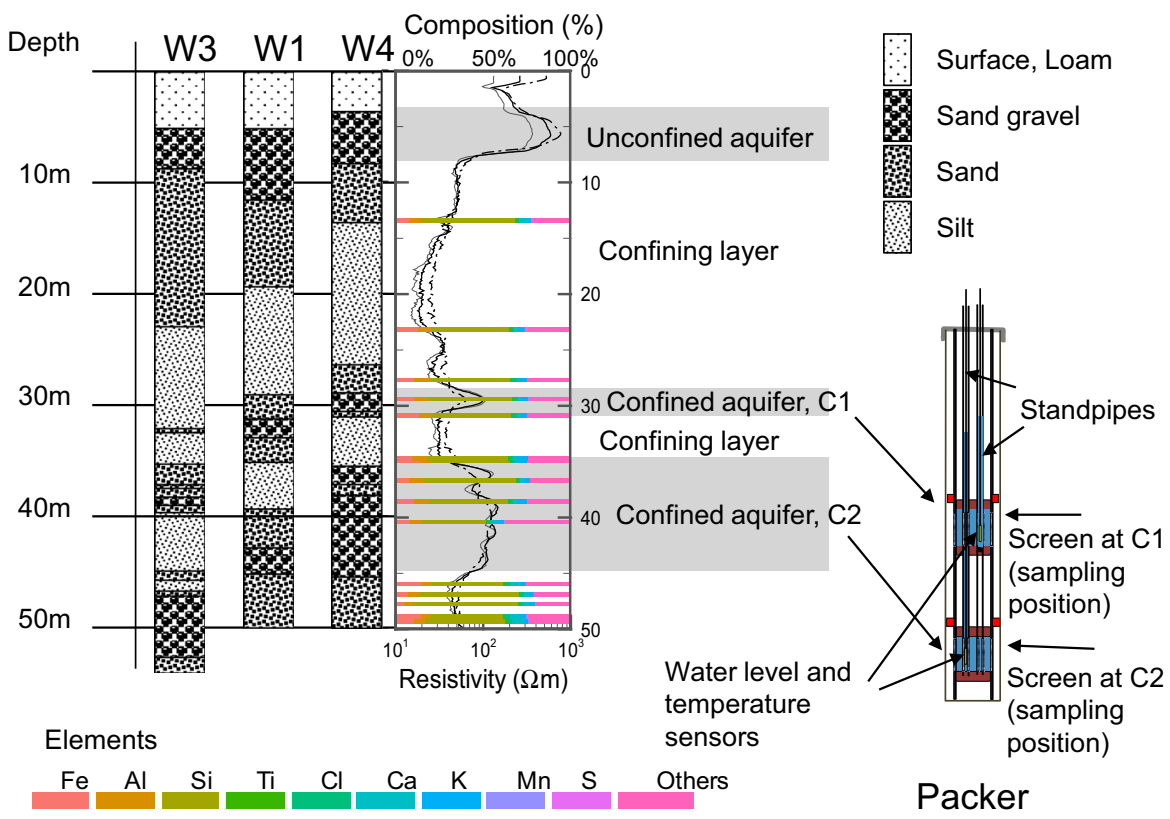

the concentration measurements were done in triplicates in each analysis. The standard deviations of the measured concentrations were less than $10 \%$. The detection limits of $\mathrm{Li}, \mathrm{B}, \mathrm{Al}, \mathrm{Cr}, \mathrm{Mn}, \mathrm{Fe}, \mathrm{Ni}, \mathrm{Cu}, \mathrm{As}, \mathrm{Se}, \mathrm{Sr}, \mathrm{Cd}, \mathrm{Sb}, \mathrm{Pb}$, and $\mathrm{Si}$ were $0.2,0.5,0.5,0.2,0.3,0.1,0.2,0.5,0.2,0.3,0.2,0.05$, $0.05,0.05$, and $1000 \mu \mathrm{g} \mathrm{L}^{-1}$, respectively.

\section{Statistical analysis}

A time series statistical analysis was used to assess the temporal variation of silicate and trace element concentrations in groundwater. Autocorrelation between pair concentrations at a series of lags from 2 to 32 weeks at 2-week intervals was calculated. Ljung-Box statistic was also performed to ensure the significant of the lags. The autocorrelation values generally range from -1 to 1 indicating how strongly the element concentrations correlated after certain period of time in a year. In this study, we considered only the significant lags at $p=0.01$ and the absolute correlation coefficients greater than 0.5 as an indication of a clear trend.

Multivariate statistical methods used in this study are not described in detail as these techniques are already well described in literature (Wold et al. 1987; Farnham et al. 2003; Chen et al. 2007). In brief, a multivariate data analysis is a statistical technique to analyze complex data sets with multiple variables. It can simplify the data by reducing the dimensionality and can hereby provide meaningful underlying information from the original data. A principal component analysis (PCA) and a hierarchical cluster analysis (HCA) are two commonly used multivariate statistical techniques when analyzing groundwater chemistry data. 
PCA transforms all element concentrations into several principal components (PC) which express some common properties of the elements based on their similarity without losing information of the original data. Each PC is independent and expresses a dominant property of all trace elements in the same component. The loading value of each trace element represents its contribution to the PC. HCA, on the other hand, is a multivariate statistical technique that can classify a large data set into some clusters or some smaller groups based on similarities defined as Euclidean distances among variables (Shyu et al. 2011). HCA has been used to split water sample data into a small number of groups that have similar hydro-geochemical characteristics (Farnham et al. 2003; Chen et al. 2007). In order to avoid the influence of spatial and temporal variations of element concentrations on the multivariate analysis output, PCA and HCA were conducted on all the element concentrations in groundwater samples collected from two aquifers in four wells during the monitoring period. In this study, PCA was conducted on a variable correlation matrix with a varimax rotation. Prior to the analysis, the concentration of each element was standardized using $z$-score with a mean and a standard deviation equal to 0 and 1 , respectively. All the standardized values were confirmed to satisfy the recommended criteria of PCA and HCA such as correlation matrix, determinant, sampling adequacy (Kaiser-MeyerOlkin's test), and sphericity (Bartlett's test) prior to the analysis (Jolliffe 2002; Hinton 2004). HCA used Ward's method (Ward 1963) with squared Euclidean distances for classifying standardized element concentrations and groundwater samples. All analyses were performed using Statistical Package for Social Science (SPSS) version 21 (IBM, CA, USA).

\section{Results and discussions}

\section{Groundwater level, temperature, rainfall ORP, EC, DO and pH}

\section{Groundwater level}

Figure $3 \mathrm{a}$ shows depths to observed piezometric surfaces for two aquifers in wells W1-W4 and monthly rainfall during the monitoring period. The water levels in all wells gradually elevated in winter of 2011 , while they stayed almost constant in 2012. This indicates that the water levels of the confined aquifers $\mathrm{C} 1$ and $\mathrm{C} 2$ are not directly influenced by precipitation. The water levels in the aquifers $\mathrm{C} 1$ and $\mathrm{C} 2$ behaved similarly indicating that the two aquifers may be hydrologically connected at some points although there is an apparent impermeable silt layer observed between two aquifers at the study site.
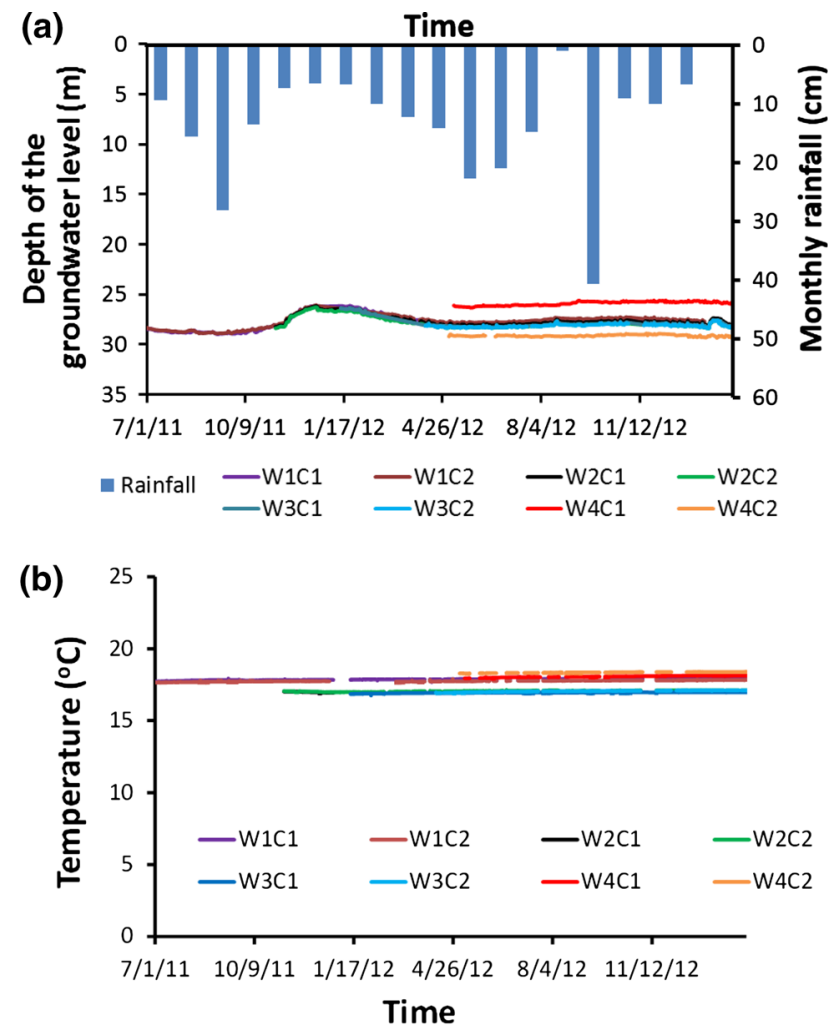

Fig. 3 Monthly rainfall, groundwater level (a) and temperature (b) in aquifers $\mathrm{C} 1$ and $\mathrm{C} 2$ of wells W1-4

\section{Environmental factors}

Groundwater temperatures stayed almost constant around $17^{\circ} \mathrm{C}$ for both aquifers during the monitoring period (Fig. 3b). This result allows us to omit discussions regarding temperature effects on trace element behavior in the aquifers.

The results of DO, ORP, EC and $\mathrm{pH}$ measured for the two confined aquifers $\mathrm{C} 1$ and $\mathrm{C} 2$ are summarized in Fig. 4. The groundwater appears to be neutral and slightly aerobic for the both aquifers. The aerobic condition was understandable because the study site is located very close to the groundwater sources such as Tama River and Kanto Mountains (Fig. 1). The study site is located about $3.5 \mathrm{~km}$ from Tama River and $35 \mathrm{~km}$ from Kanto Mountains in Kanagawa prefecture (Endo and Ishii 1984; Endo 1992; Imaizumi et al. 2000). The groundwater is therefore expected to be influenced by relatively high-DO content water from those water sources. Graves (1987) reported that DO in groundwater was usually highest at the time of recharge because it was formed from meteoric or atmospheric oxygen. The DO was then gradually decreased with the increase in residence time due to biochemical reactions (Graves 1987), and, in such reactions, oxygen was always consumed and never produced (Wilson 1995). The DO and 


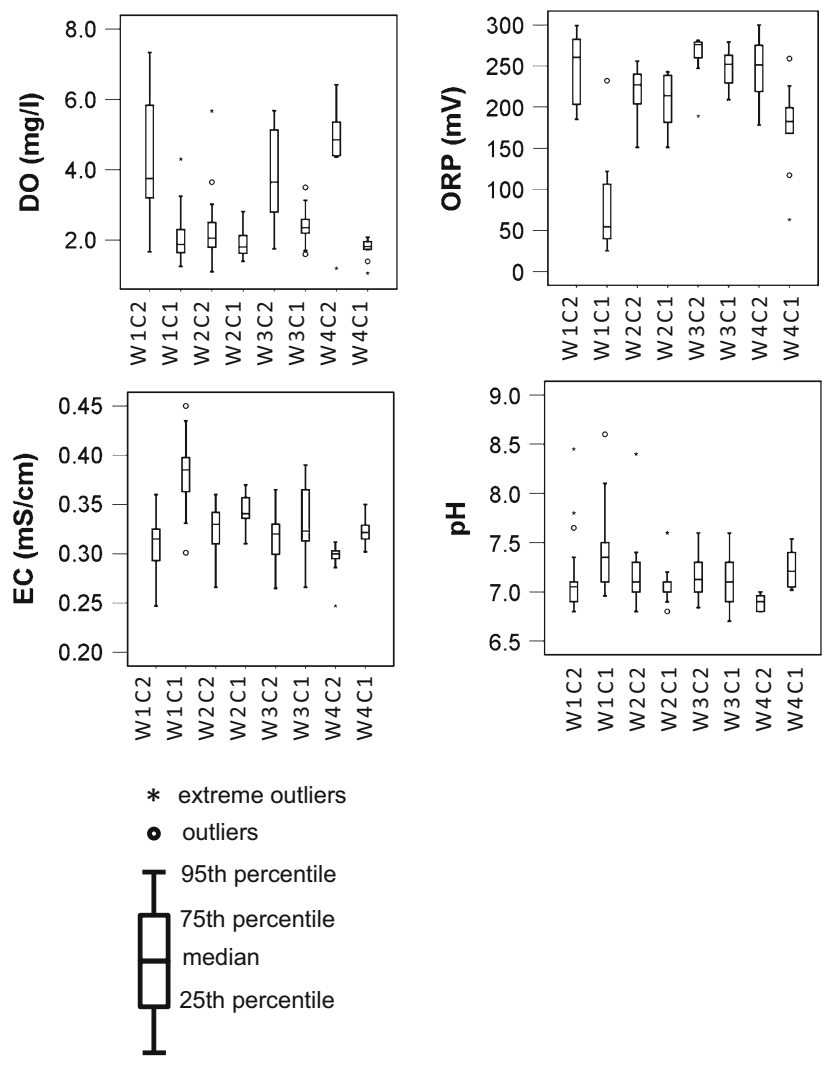

Fig. 4 pH. DO, EC and ORP in groundwater in aquifers $\mathrm{C} 1$ and $\mathrm{C} 2$ of wells W1-4

ORP in the $\mathrm{C} 2$ aquifer were higher than those in the $\mathrm{C} 1$ aquifer in W1, W3, and W4 (Fig. 4). The deeper aquifer (C2) is expected to have a lower DO than the shallower aquifer (C1), as oxygen is expected to be depleted in deeper aquifers. However, the trend was reversed in this study site, which could be subjected to differences in residence time in the two aquifers, i.e., the $\mathrm{C} 2$ aquifer may have a younger groundwater than the $\mathrm{C} 1$ aquifer. Groundwater flow rates observed for $\mathrm{C} 1$ and $\mathrm{C} 2$ at the beginning of the experimental period were 2.57 and 8.73 $10^{-5} \mathrm{~cm} \mathrm{~s}^{-1}$, respectively. The observed flow rates suggest that the residence time of groundwater in $\mathrm{C} 1$ was longer than that in $\mathrm{C} 2$.

\section{Trace elements in natural groundwater in Fuchu}

Table 1 shows average trace element concentrations $\left(\mu \mathrm{g} \mathrm{L}^{-1}\right.$ ) in two aquifers, $\mathrm{C} 1$ and $\mathrm{C} 2$, from all four wells during the monitoring period. Temporal variations of trace elements are presented in Fig. 5. The trace elements were detected in the aquifers with various concentration ranges. $\mathrm{Si}$ has the highest concentration $\left(12-31 \mathrm{mg} \mathrm{L}^{-1}\right)$, whereas the concentrations of $\mathrm{Cd}, \mathrm{Sb}$, and $\mathrm{Pb}$ were less than $3.3 \mu \mathrm{g} \mathrm{L}{ }^{-1}$. The Mn concentration ranged from below the detection limit (DL) to $302.5 \mu \mathrm{g} \mathrm{L}^{-1}$. The Si concentrations in this study
Table 1 Concentrations of elements in groundwater in Fuchu, Tokyo

\begin{tabular}{lllll}
\hline Element & \multicolumn{3}{l}{ Concentration $\left(\mu \mathrm{g} \mathrm{L}^{-1}\right)$} \\
\cline { 2 - 5 } & Minimum & Maximum & Mean & Std. deviation \\
\hline $\mathrm{Li}$ & 2.0 & 7.4 & 4.7 & 1.3 \\
$\mathrm{~B}$ & 10.4 & 115.3 & 44.0 & 27.9 \\
$\mathrm{Al}$ & 0.12 & 26.7 & 5.2 & 4.4 \\
$\mathrm{Cr}$ & 0.80 & 5.2 & 1.8 & 1.0 \\
$\mathrm{Mn}$ & $\mathrm{ND}$ & 302.5 & 82.0 & 71.4 \\
$\mathrm{Fe}$ & 4.50 & 161.4 & 31.0 & 27.7 \\
$\mathrm{Ni}$ & 3.42 & 141.6 & 32.9 & 29.1 \\
$\mathrm{Cu}$ & $\mathrm{ND}$ & 28.1 & 3.7 & 4.5 \\
$\mathrm{As}$ & 0.26 & 7.1 & 1.8 & 1.4 \\
$\mathrm{Se}$ & 0.75 & 11.3 & 4.7 & 2.4 \\
$\mathrm{Sr}$ & 132 & 254.6 & 184.4 & 25.7 \\
$\mathrm{Cd}$ & $\mathrm{ND}$ & 0.3 & 0.1 & 0.05 \\
$\mathrm{Sb}$ & $\mathrm{ND}$ & 0.7 & 0.1 & 0.1 \\
$\mathrm{~Pb}$ & $\mathrm{ND}$ & 3.3 & 0.3 & 0.6 \\
$\mathrm{Si}$ & 12017 & 31088 & 18855 & 4581 \\
\hline
\end{tabular}

$N D$ not detected (under detection limit)

fall in a common range of $1-30 \mathrm{mg} \mathrm{L}^{-1}$ natural water (Hem 1989). The mean concentration of $\mathrm{Si}$ in groundwater in the United States is reported to be $17 \mathrm{mg} \mathrm{L}^{-1}$ (Davis 1964). Arsenic (As) was detected in all groundwater samples in the concentration range from 0.26 to $7.1 \mu \mathrm{g} \mathrm{L}^{-1}$. The As concentrations were lower than the environmental quality standard of $10 \mu \mathrm{g} \mathrm{L}^{-1}$ issued by the Japanese Ministry of the Environment (JMOE 2003). Lead (Pb) and Chromium (Cr) were detected in some water samples with concentrations ranging from below DL to 3.3 and $5.2 \mu \mathrm{g} \mathrm{L}^{-1}$, respectively. The levels of $\mathrm{Pb}$ and $\mathrm{Cr}$ were also lower than the quality standard limits by JMOE (JMOE 2003). The average Mn concentration was $82 \mu \mathrm{g} \mathrm{L}^{-1}$. While the Mn level in drinking water is not yet restricted in Japan, the maximum Mn concentration recommended in public water supplies in the United States is $50 \mu \mathrm{g} \mathrm{L}^{-1}$. However, there is still no legal limit provided by the U.S Environmental Protection Agency (Hem 1989). All the Mn concentrations were lower than $400 \mu \mathrm{g} \mathrm{L}^{-1}$ that is given in the WHO drinking water guideline (WHO 2011).

Chemical composition of groundwater depends on many factors such as geochemical properties of local geology. It can thus vary markedly between aquifers and between wells. Figure 6 shows differences in distributions of the trace element concentrations between aquifers and wells. The average concentrations of $\mathrm{Li}, \mathrm{Fe}, \mathrm{Mn}$, $\mathrm{Ni}, \mathrm{As}, \mathrm{Se}$, and $\mathrm{Si}$ in the $\mathrm{C} 1$ aquifer were higher than those in the $\mathrm{C} 2$ aquifer whereas the average $\mathrm{B}$ concentration was lower in the $\mathrm{C} 1$ aquifer than that in the $\mathrm{C} 2$ aquifer (Fig. 6). There was no distinct difference among the concentrations of $\mathrm{Al}, \mathrm{Cr}, \mathrm{Cu}, \mathrm{Zn}, \mathrm{Cd}, \mathrm{Sb}$, and $\mathrm{Pb}$ 
Fig. 5 Temporal variation of element concentrations $\left(\mu \mathrm{g} \mathrm{L}^{-1}\right)$ in groundwater of wells W1-4
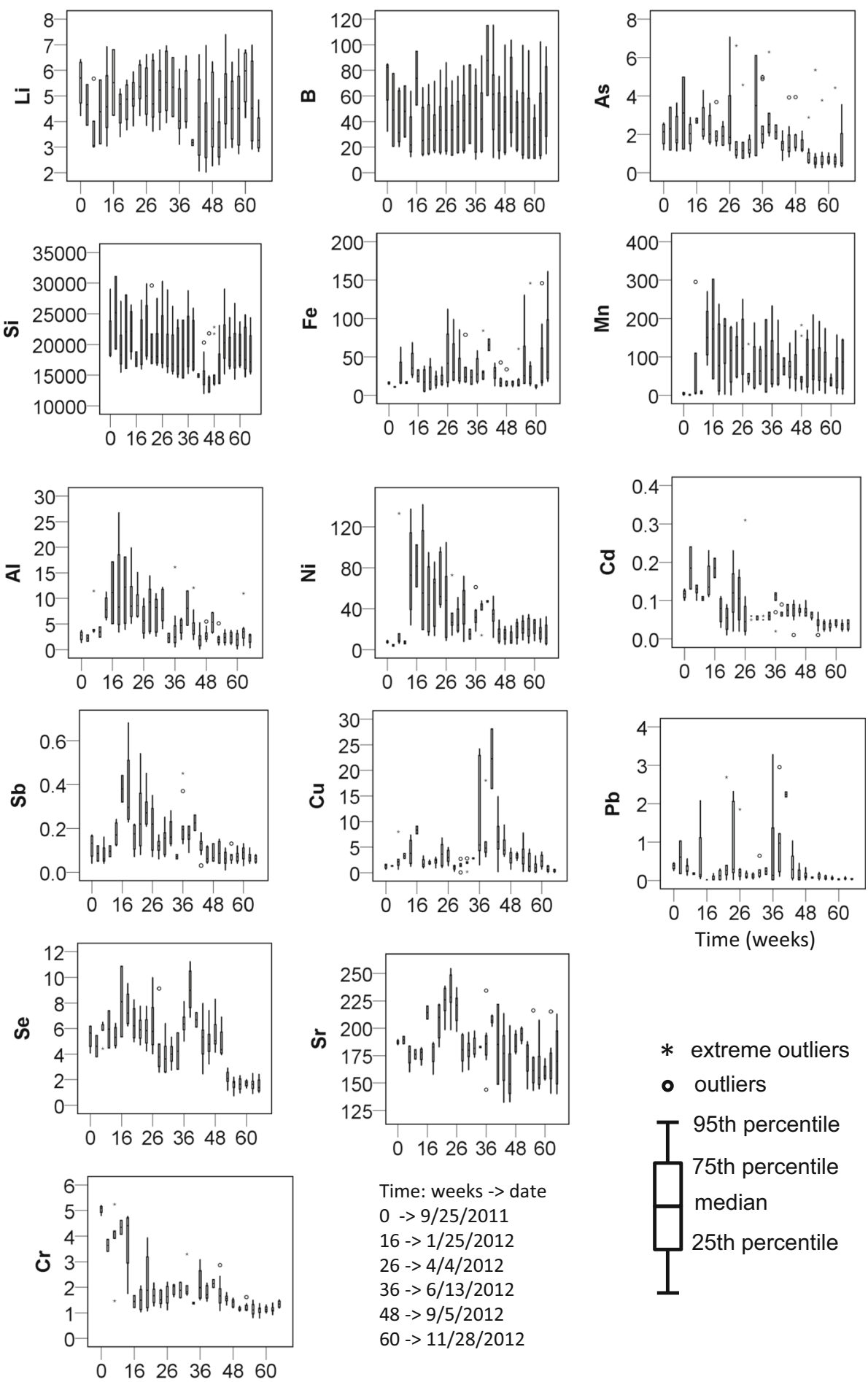

Time: weeks -> date $0 \rightarrow 9 / 25 / 2011$

$16 \rightarrow 1 / 25 / 2012$

$26->4 / 4 / 2012$

$36 \rightarrow 6 / 13 / 2012$

$48->9 / 5 / 2012$

$60->11 / 28 / 2012$
* extreme outliers

- outliers

$\coprod^{\text {25th percentile }} \begin{aligned} & \text { 95th percentile } \\ & \text { median percentile }\end{aligned}$ between the two aquifers. The composition of trace elements in groundwater is determined by mineral dissolution and/or precipitation, and sorption/desorption from particles/minerals (Mason 2013). Redox reaction and changes in microbial activities within the aquifer can also lead to differences in concentrations especially for the trace elements that are easily transformed between oxidation states. The DO in the $\mathrm{C} 1$ aquifer was lower than that in the $\mathrm{C} 2$ aquifer (Fig. 4). The differences in DO could lead to the differences in microbial activities and oxidation/reduction reactions especially for oxidation/reduction sensitive elements such as As, Fe, and Mn. Soluble $\mathrm{Mn}$ in groundwater exists in a form of $\mathrm{Mn}^{2+}$. $\mathrm{Fe}$ and $\mathrm{Mn}$ are usually more soluble in oxygen depleted 
Fig. 6 Boxplots for element concentrations $\left(\mu \mathrm{g} \mathrm{L}^{-1}\right)$ in groundwater in aquifers $\mathrm{C} 1$ and C2 of wells W1-4
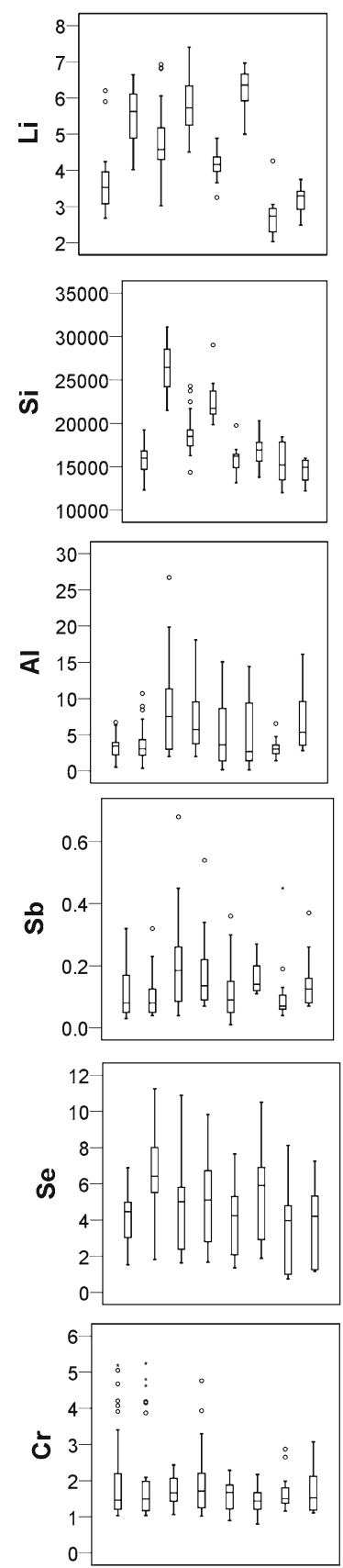
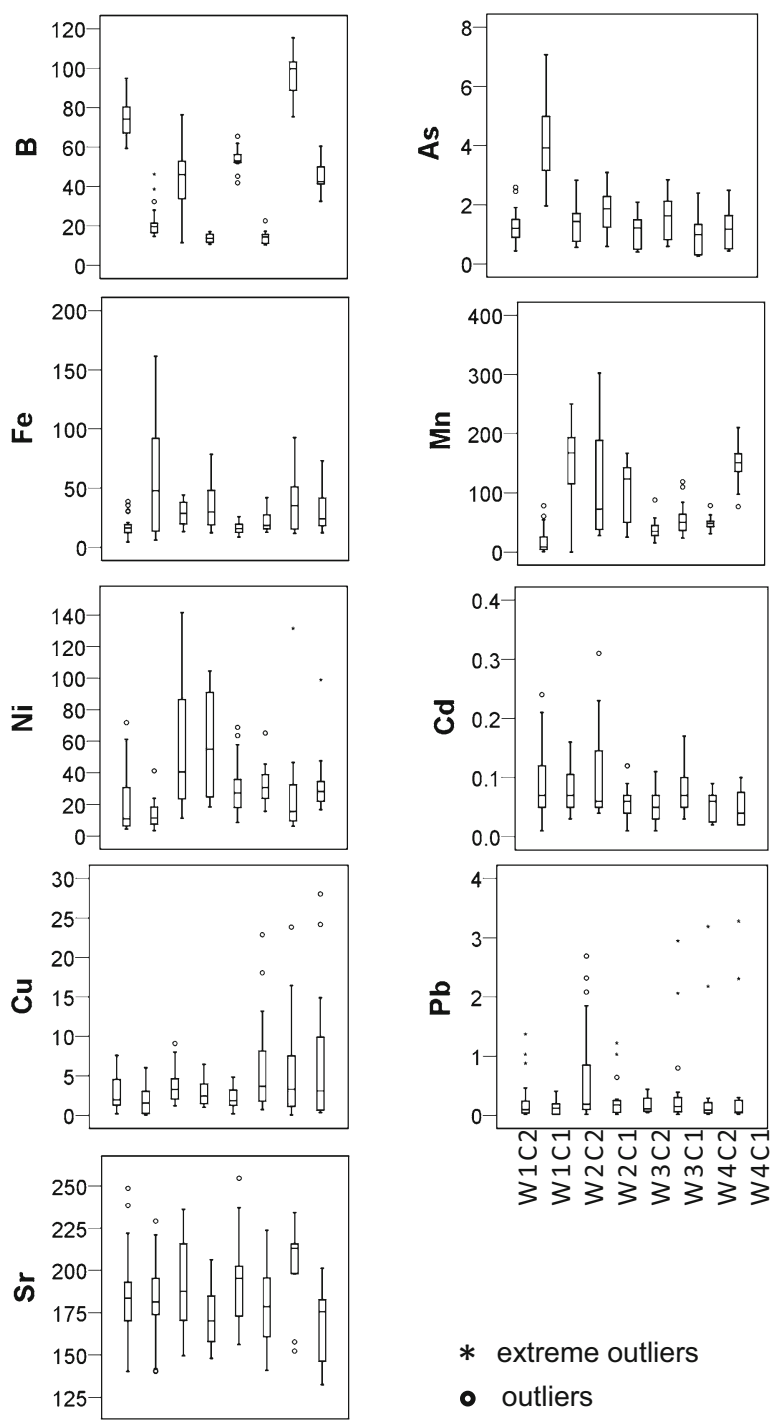

* extreme outliers

- outliers

$\coprod^{75 \text { th percentile }} \begin{aligned} & \text { 95th percentile } \\ & \text { median }\end{aligned}$ groundwater because, in oxidizing water, Fe and $\mathrm{Mn}$ tend to precipitate as insoluble oxy-hydroxides, $\mathrm{Fe}_{2} \mathrm{O}_{3}$, $\mathrm{Fe}(\mathrm{OH})_{3}$, and $\mathrm{MnO}_{2}$ (Hem 1989; Chen et al. 2007; Shand and Edmunds 2008). Chen et al. (2007) also reported that reduced groundwater exhibited higher $\mathrm{Mn}$ concentrations. Although $\mathrm{Mn}$ and Fe both precipitate in oxidation processes in weathering environment, divalent manganese is more stable towards oxidation in water compared to ferrous iron (Hem, 1989). In natural water systems, dissolved manganese will be at the $2+$ oxidation state. The $\mathrm{C} 1$ aquifer had lower DO than the $\mathrm{C} 2$ aquifer, which resulted in higher concentrations of soluble Fe and $\mathrm{Mn}$ in the $\mathrm{C} 1$ aquifer as compared to those in the $\mathrm{C} 2$ aquifer (Fig. 6). Although As solubility in oxidizing condition is higher than that in reducing condition (Weiner 2013), As is also strongly adsorbed and coprecipitated with iron and manganese oxides/hydroxides available in groundwater. As was then released from those materials under reducing condition (Anawar et al. 2003; Shand and Edmunds 2008). Higher As concentrations were observed in the $\mathrm{C} 1$ aquifer in this study. Although the difference could be explained by the release 
Table 2 Autocorrelation coefficients of 15 elements at 16 lags

\begin{tabular}{lrrrrrrrrrrrrrrrrr}
\hline $\begin{array}{l}\text { Lag } \\
\text { (weeks) }\end{array}$ & $\mathrm{Li}$ & $\mathrm{B}$ & $\mathrm{Al}$ & $\mathrm{Cr}$ & $\mathrm{Mn}$ & $\mathrm{Fe}$ & $\mathrm{Ni}$ & $\mathrm{Cu}$ & $\mathrm{As}$ & $\mathrm{Se}$ & $\mathrm{Sr}$ & $\mathrm{Cd}$ & $\mathrm{Sb}$ & $\mathrm{Pb}$ & $\mathrm{Si}$ \\
\hline 2 & 0.10 & 0.15 & $\mathbf{0 . 5 8}$ & $\mathbf{0 . 5 7}$ & 0.04 & 0.27 & 0.32 & 0.15 & 0.45 & $\mathbf{0 . 7 3}$ & $\mathbf{0 . 5 3}$ & 0.36 & 0.43 & 0.17 & 0.38 \\
4 & 0.13 & 0.08 & $\mathbf{0 . 5 8}$ & 0.20 & 0.36 & -0.01 & $\mathbf{0 . 5 1}$ & $\mathbf{0 . 5 0}$ & 0.42 & 0.48 & 0.30 & 0.33 & 0.36 & 0.39 & 0.23 \\
6 & 0.17 & 0.12 & 0.28 & 0.11 & -0.16 & -0.04 & 0.19 & -0.01 & 0.15 & 0.34 & 0.16 & 0.35 & 0.30 & -0.15 & 0.12 \\
8 & -0.17 & -0.15 & 0.40 & 0.34 & 0.25 & -0.10 & 0.31 & 0.01 & 0.17 & 0.20 & -0.01 & 0.28 & 0.22 & -0.12 & 0.19 \\
10 & 0.02 & -0.01 & 0.21 & 0.41 & 0.00 & -0.11 & 0.12 & -0.09 & 0.11 & 0.05 & 0.04 & 0.30 & 0.05 & -0.12 & 0.24 \\
12 & 0.02 & -0.12 & 0.21 & 0.24 & -0.05 & -0.06 & 0.05 & -0.14 & 0.02 & -0.05 & -0.04 & 0.09 & 0.04 & 0.06 & 0.05 \\
14 & -0.07 & -0.16 & -0.02 & -0.05 & -0.11 & -0.09 & -0.02 & -0.17 & 0.02 & -0.11 & -0.04 & 0.28 & -0.01 & -0.01 & -0.02 \\
16 & -0.12 & -0.12 & -0.08 & -0.08 & -0.23 & -0.12 & -0.11 & -0.20 & -0.02 & -0.17 & -0.03 & 0.03 & -0.11 & 0.02 & 0.11 \\
18 & -0.05 & -0.20 & -0.21 & -0.05 & 0.03 & -0.10 & -0.13 & -0.24 & 0.02 & -0.15 & 0.05 & -0.10 & 0.00 & -0.13 & 0.17 \\
20 & -0.22 & -0.27 & -0.10 & 0.03 & -0.12 & -0.13 & -0.04 & -0.10 & -0.16 & -0.08 & -0.11 & 0.05 & 0.05 & -0.27 & -0.03 \\
22 & 0.03 & -0.13 & -0.17 & -0.05 & -0.07 & 0.06 & -0.24 & -0.22 & -0.22 & -0.01 & -0.03 & 0.03 & -0.13 & -0.23 & -0.08 \\
24 & -0.12 & 0.15 & -0.07 & -0.06 & -0.19 & 0.21 & -0.11 & -0.02 & -0.08 & -0.07 & -0.02 & 0.06 & -0.07 & -0.21 & -0.08 \\
26 & 0.00 & -0.06 & -0.20 & -0.05 & -0.02 & 0.14 & -0.14 & -0.06 & -0.16 & -0.01 & -0.01 & 0.00 & -0.10 & -0.11 & -0.11 \\
28 & 0.07 & -0.01 & -0.20 & 0.01 & -0.01 & 0.04 & -0.01 & 0.02 & 0.06 & 0.12 & 0.06 & -0.03 & -0.16 & 0.00 & -0.12 \\
30 & -0.06 & -0.01 & -0.29 & 0.04 & 0.05 & 0.00 & -0.21 & 0.06 & -0.10 & 0.08 & -0.19 & -0.04 & -0.20 & -0.01 & -0.14 \\
32 & 0.13 & -0.14 & -0.22 & 0.04 & -0.08 & 0.10 & -0.13 & 0.05 & -0.01 & 0.01 & -0.21 & -0.08 & -0.23 & 0.01 & -0.07 \\
\hline
\end{tabular}

Figures in bolditalics indicates absolute coefficients greater than 0.5 and the lag is significant at the 0.01 level (2-tailed)

of As under reducing condition, further investigation will be needed to understand more detailed mechanisms.

Time series analysis shows that the autocorrelation coefficients of most of elements at different time lags were insignificant at a confidence level of 0.01 , and the absolute correlations were rather low $(<0.5)$ except for $\mathrm{Al}, \mathrm{Cr}, \mathrm{Ni}$, $\mathrm{Cu}$, Se and $\mathrm{Sr}$ at certain lags (Table 2). It indicates that the variations of the trace elements in the aquifers did not have clear temporal trends (Fig. 5). The element concentrations were controlled by many parameters such as hydrological condition, physical and chemical conditions of groundwater and local rock, soil etc. at different temporal scales. From the time series analysis, it can be concluded that the element concentrations were independent of time.

$\mathrm{Al}, \mathrm{Cr}, \mathrm{Ni}, \mathrm{Cu}, \mathrm{Se}$ and $\mathrm{Sr}$ have higher correlations $(\geq 0.5)$ at the initial lags of 2 or 4 weeks, although the correlations were rather low $(\leq 0.73)$. There are almost no correlations after 10-12 weeks (Table 2) indicating that there are no clear seasonal trends in these element concentrations. The correlations of $\mathrm{Al}, \mathrm{Se}$, and $\mathrm{Sr}$ gradually decreased with time, and their ranges are about 12, 8 and 6 weeks, respectively (Table 2). It suggests weak temporal trends for $\mathrm{Al}$, Se and $\mathrm{Sr}$ concentrations.

Although there were no clear trends in the temporal variation of all elements, the concentrations of several elements such as $\mathrm{B}, \mathrm{As}, \mathrm{Cu}, \mathrm{Se}, \mathrm{Cr}$, and $\mathrm{Pb}$ largely varied between 35 and 45 weeks that corresponds to June 1-August 1 in the summer season in Japan (Fig. 5). There were also several anomalous concentrations during this period. The changes were possibly caused by the dissolution/sorption of these elements from/to minerals and soils due to a higher groundwater consumption in the summer in Fuchu city. The higher water consumption altered the faster renewal rate of local groundwater. The new groundwater could have different element concentrations, and it could interact with local minerals and soil through dissolution/sorption processes. These processes may be responsible for the large variations in the element concentrations in the summer. The dissolution/sorption rates depend on the concentrations and the characteristics of each element in minerals and soil thus the changes in the concentrations were different among elements (Fig. 5). Further studies on the dissolution of elements from minerals and soils are needed to verify this assumption. Figure 5 shows that several concentrations of $\mathrm{Cu}$ and $\mathrm{Pb}$ in the summer were significantly higher than concentrations in other periods. The higher concentrations of $\mathrm{Cu}$ and $\mathrm{Pb}$ and several elements in the summer were also observed in Shenzhen groundwater in China (Chen et al. 2007) and Chenai groundwater in India (Ramesh 1999).

\section{Correlation between variables}

A number of studies reported that there are some degrees of correlation among elements in groundwater. Elements with similar transport characteristics or same origin are subject to higher correlations. A correlation matrix among the elements obtained in this study is shown in Table 3. There are relatively higher correlations between $\mathrm{Li}$ and $\mathrm{B}$ $(r=-0.73), \mathrm{Li}$ and $\mathrm{Si}(r=0.62), \mathrm{Ni}$ and $\mathrm{Al}(r=0.67)$, $\mathrm{Ni}$ and $\mathrm{Sb}(r=0.79)$, As and $\mathrm{Fe}(r=0.52)$, As and $\mathrm{Se}$ $(r=0.68)$, As and $\mathrm{Si}(r=0.69)$, and $\mathrm{Pb}$ and $\mathrm{Cu}$ 
Table 3 Pearson correlation coefficients for the 15 elements

\begin{tabular}{|c|c|c|c|c|c|c|c|c|c|c|c|c|c|c|c|}
\hline & $\mathrm{Li}$ & B & $\mathrm{Al}$ & $\mathrm{Cr}$ & $\mathrm{Mn}$ & $\mathrm{Fe}$ & $\mathrm{Ni}$ & $\mathrm{Cu}$ & As & $\mathrm{Se}$ & $\mathrm{Sr}$ & $\mathrm{Cd}$ & $\mathrm{Sb}$ & $\mathrm{Pb}$ & $\mathrm{Si}$ \\
\hline $\mathrm{Li}$ & 1.00 & & & & & & & & & & & & & & \\
\hline B & -0.73 & 1.00 & & & & & & & & & & & & & \\
\hline $\mathrm{Al}$ & 0.11 & -0.12 & 1.00 & & & & & & & & & & & & \\
\hline $\mathrm{Cr}$ & -0.02 & 0.09 & 0.17 & 1.00 & & & & & & & & & & & \\
\hline $\mathrm{Mn}$ & 0.20 & -0.44 & 0.39 & -0.10 & 1.00 & & & & & & & & & & \\
\hline $\mathrm{Fe}$ & 0.12 & -0.20 & 0.00 & -0.01 & 0.45 & 1.00 & & & & & & & & & \\
\hline $\mathrm{Ni}$ & 0.14 & -0.13 & 0.67 & 0.11 & 0.43 & 0.04 & 1.00 & & & & & & & & \\
\hline $\mathrm{Cu}$ & 0.01 & 0.08 & 0.15 & 0.07 & 0.05 & 0.00 & 0.34 & 1.00 & & & & & & & \\
\hline As & 0.41 & -0.41 & 0.02 & 0.17 & 0.48 & 0.52 & -0.01 & 0.08 & 1.00 & & & & & & \\
\hline $\mathrm{Se}$ & 0.30 & -0.24 & 0.28 & 0.27 & 0.33 & 0.06 & 0.30 & 0.38 & 0.68 & 1.00 & & & & & \\
\hline $\mathrm{Sr}$ & 0.02 & 0.31 & 0.30 & 0.07 & 0.04 & -0.13 & 0.25 & 0.05 & 0.10 & 0.38 & 1.00 & & & & \\
\hline $\mathrm{Cd}$ & 0.01 & -0.02 & 0.38 & 0.07 & 0.21 & -0.07 & 0.32 & 0.00 & 0.03 & 0.14 & 0.25 & 1.00 & & & \\
\hline $\mathrm{Sb}$ & 0.17 & -0.08 & 0.69 & 0.12 & 0.30 & -0.05 & 0.79 & 0.36 & 0.10 & 0.44 & 0.38 & 0.42 & 1.00 & & \\
\hline $\mathrm{Pb}$ & 0.04 & 0.08 & 0.28 & 0.14 & 0.09 & 0.07 & 0.45 & 0.60 & 0.08 & 0.31 & 0.24 & 0.42 & 0.41 & 1.00 & \\
\hline $\mathrm{Si}$ & 0.62 & -0.56 & -0.01 & 0.18 & 0.39 & 0.39 & -0.04 & -0.19 & 0.68 & 0.30 & 0.01 & -0.01 & -0.03 & -0.08 & 1.00 \\
\hline
\end{tabular}

Figures in bolditalics indicates absolute values greater than 0.5 and the correlation is significant at the 0.01 level (2-tailed)

$(r=0.60)$, all at a significance level $p<0.01$. However, $\mathrm{Cr}$ has no significant correlation with other trace elements $(r<0.3)$; therefore $\mathrm{Cr}$ was not included in the subsequent multivariate analyses. Chen et al. (2007) found that there are significant correlations between $\mathrm{Cr}$ and $\mathrm{As}(r=0.81)$, and $\mathrm{Pb}$ and $\mathrm{Cu}(r=0.82)$ in groundwater from coastal areas of Zhenzhen, China. Differences between the findings of Chen et al. (2007) and this study indicate that correlations among trace elements are not only depended on chemical properties but also local groundwater hydrochemical conditions. It should be also noted that correlations among elements tend to decrease as the scales of study sites increase especially when groundwater chemistry varies markedly with scale. For example, Shyu et al. (2011) reported that there are no significant correlations among heavy metals such as $\mathrm{As}, \mathrm{Cd}, \mathrm{Cr}, \mathrm{Cu}, \mathrm{Pb}$, and $\mathrm{Zn}$ collected from 319 regional monitoring wells in Taiwan.

\section{Principal component analysis}

Table 4 shows the loadings of each trace element in the three extracted principle components (PC). Figure 7a is the loading plot for the two major components, $\mathrm{PC} 1$ and PC2. The first three PCs can explain $61.3 \%$ of the total variance. The other principal components account less than $8 \%$ of the total variance respectively thus they can be ignored. The PC1, which explains $24.7 \%$ of the total variance, consists of $\mathrm{Li}, \mathrm{B}, \mathrm{Mn}, \mathrm{Fe} \mathrm{As}$, and $\mathrm{Si}$. Trace elements in groundwater should reflect the physical and chemical characteristics of the groundwater such as local temperatures, groundwater sources, chemical compositions of aquifer materials and weathering reactions (Tanji
Table 4 Principal component loadings

\begin{tabular}{lcrr}
\hline Element & \multicolumn{3}{c}{ Principal component } \\
\cline { 2 - 4 } & PC1 & PC2 & \multicolumn{1}{c}{ PC3 } \\
\hline $\mathrm{Li}$ & $\mathbf{0 . 7 1}$ & 0.17 & -0.12 \\
$\mathrm{~B}$ & $-\mathbf{0 . 7 7}$ & -0.18 & 0.31 \\
$\mathrm{Al}$ & 0.07 & $\mathbf{0 . 8 5}$ & 0.09 \\
$\mathrm{Mn}$ & $\mathbf{0 . 6 1}$ & 0.41 & 0.04 \\
$\mathrm{Fe}$ & $\mathbf{0 . 5 6}$ & -0.16 & 0.13 \\
$\mathrm{Ni}$ & 0.07 & $\mathbf{0 . 8 3}$ & 0.26 \\
$\mathrm{Cu}$ & -0.06 & 0.10 & $\mathbf{0 . 7 7}$ \\
$\mathrm{As}$ & $\mathbf{0 . 8 3}$ & -0.13 & 0.36 \\
$\mathrm{Se}$ & 0.49 & 0.19 & $\mathbf{0 . 6 4}$ \\
$\mathrm{Sr}$ & -0.08 & 0.32 & 0.43 \\
$\mathrm{Cd}$ & -0.03 & $\mathbf{0 . 6 0}$ & 0.10 \\
$\mathrm{Sb}$ & 0.07 & $\mathbf{0 . 8 2}$ & 0.35 \\
$\mathrm{~Pb}$ & -0.04 & 0.34 & $\mathbf{0 . 7 0}$ \\
$\mathrm{Si}$ & $\mathbf{0 . 8 6}$ & -0.07 & -0.09 \\
Eigenvalues & 4.1 & 3.0 & 1.4 \\
$\%$ Variance explained & 24.7 & 21.2 & 15.4 \\
\% Cumulative variance & 24.7 & 45.9 & 61.3 \\
\hline Extration & &
\end{tabular}

Extraction method: principal component analysis

Rotation method: Varimax with Kaiser

Rotation converged in five iterations

Bold means the condition when the $p$ value of the "test of significance (2-tailed)" (the Pearson's correlation coeficients >0.5) was smaller than 0.01 ( $p$ value critical)

and Valoppi 1989). Among them, the chemical composition of the rock, one of the major aquifer materials, was reported as one of the major factors influencing groundwater chemistry (White et al. 1963). In this study, Si has 
(a)

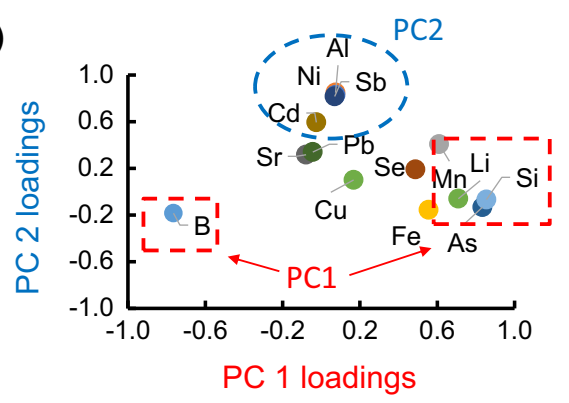

(b)

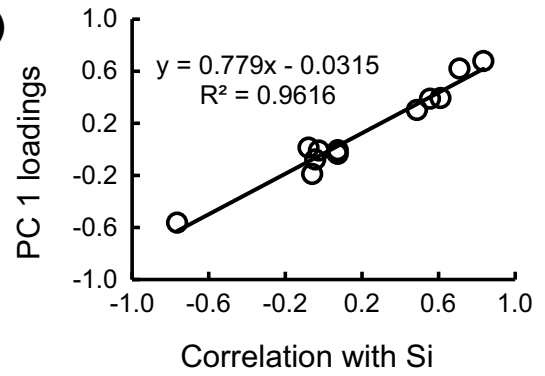

(c)

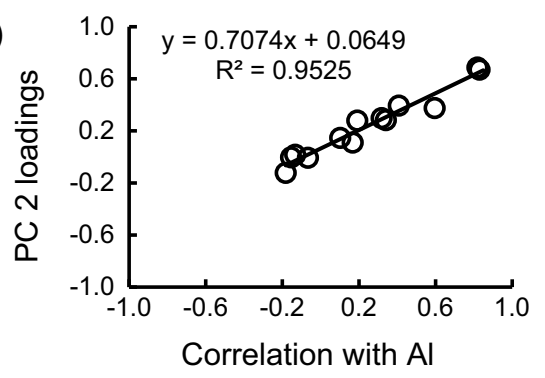

Fig. 7 Relationship between principal components (a), principal component loadings and the correlations of $\mathrm{Si}$ and $\mathrm{Al}$ with other trace elements (b) and (c)

the largest loading (0.855) in the PC1. There is a strong linear relationship $(r=0.98)$ between the PC1 loadings and correlation coefficients between $\mathrm{Si}$ and other trace elements (Fig. 7b). It suggests that the trace elements in the PC1 are controlled by the silicate minerals. Trace elements in the $\mathrm{PC} 1$ such as $\mathrm{Li}, \mathrm{B}, \mathrm{Fe}$ and $\mathrm{Si}$, may originate from igneous rock minerals with a high silicate content (Hem 1989), which were indeed found in Kanto Mountains (Takei 1975). Concentrations of $\mathrm{Si}$ in groundwater at neutral $\mathrm{pH}$ are controlled by chalcedony, an amorphous silica phase (Appelo and Postma 2005; Shand and Edmunds 2008). Manganese, another element in $\mathrm{PC} 1$, is not an essential constituent of any common silicate rock minerals but it can substitute for $\mathrm{Fe}, \mathrm{Mg}$ or $\mathrm{Ca}$ in the silicate structures (Hem 1989). Silicate was also reported as one of the major phase containing As in groundwater (Anawar et al. 2003). This supports the dominance of $\mathrm{Si}$ among the trace elements in the PC1. A study on groundwater quality in Pico Island in Portugal (Cruz and Silva 2000) found that the dissolution of silicate minerals was responsible for changes in groundwater chemical compositions. Furthermore, the elements in the $\mathrm{PC} 1$ are known for their mobile properties in groundwater. Groundwater in the study area is neutral and slightly aerobic. Under such conditions, dissolved boron mainly exists as uncharged species in a form of monomeric or polymeric species of boric acid, $\mathrm{H}_{3} \mathrm{BO}_{3}$ or written as $\mathrm{B}(\mathrm{OH})_{3(\mathrm{aq})}$. Dissolved $\mathrm{Si}$ mainly exists in a hydrated form as $\mathrm{H}_{4} \mathrm{SiO}_{4}(\mathrm{aq})$ or $\mathrm{Si}(\mathrm{OH})_{4}$, and $\mathrm{Si}$ neither presents as any ionic species nor extensively absorb to other mineral surfaces (Hem 1989). Both Li and B are considered as inert solutes in groundwater, thus their isotopes ${ }^{6} \mathrm{Li}$ and ${ }^{11} \mathrm{~B}$ have been used as groundwater tracers in many studies (Hogan and Blum 2003; Négrel et al. 2010). This suggests higher mobility of Li, B, and $\mathrm{Si}$ in groundwater.

$\mathrm{Mn}, \mathrm{Fe}$, and As are sensitive to the ORP condition in groundwater (Weiner 2013). $\mathrm{Mn}$ and $\mathrm{Fe}$ in groundwater mainly exist as $\mathrm{Mn}^{2+}$ and $\mathrm{Fe}^{2+} \cdot \mathrm{Mn}^{2+}$ is usually more stable in groundwater than $\mathrm{Fe}^{2+}$. As is normally in the form of oxyanions such as $\mathrm{AsO}_{4}{ }^{2-}$ and $\mathrm{H}_{2} \mathrm{AsO}_{4}{ }^{-}$. They appear mainly in arsenopyrite ( $\mathrm{FeAsS}$ ) and arsenic-rich pyrite minerals in groundwater (Langmuir 1997; Shand and Edmunds 2008). Under aerobic condition, dissolved As is more stable than dissolved $\mathrm{Fe}$ and $\mathrm{Mn}$, which also agreed with the loadings in PC1: As $>\mathrm{Fe}>\mathrm{Mn}$ (Table 4). Li, As, $\mathrm{Fe}, \mathrm{Mn}$, and $\mathrm{Si}$, which have positive loadings, are associated with the higher concentrations in the $\mathrm{C} 1$ aquifer as compared to the $\mathrm{C} 2$ aquifer (Fig. 6). As shown in Fig. 4, ORP and DO of the $\mathrm{C} 1$ aquifer were lower than those of the $\mathrm{C} 2$ aquifer.

$\mathrm{B}$ has the only negative PC1 loading (-0.770). This may be related to its solubility in groundwater in the presence of $\mathrm{Si}$. B is negatively correlated with $\mathrm{Si}(r=-0.56)$ (Table 3). As both Si and B exist in soluble uncharged molecules in groundwater, they presumably have similar properties. The richness of $\mathrm{Si}$ in groundwater therefore may result in less availability of $\mathrm{B}$ due to competitive solubility. This can explain the negative correlation between $\mathrm{Si}$ and $\mathrm{B}$, and the negative loading of B in the PC1 (Table 4). Correlated-mechanism between $\mathrm{Si}$ and $\mathrm{B}$ is still very limited in literature, thus further studies are needed to clarify their relationship.

The PC2 includes $\mathrm{Al}, \mathrm{Ni}, \mathrm{Cd}$ and $\mathrm{Sb}$ and explains $21.2 \%$ of the total variance. $\mathrm{Al}$ has the largest loading in the PC2 (0.849). The loadings of the other elements in the PC2 strongly correlated $(r=0.977)$ with the correlation coefficients with $\mathrm{Al}$ (Fig. 7c). This suggests that the elements in the $\mathrm{PC} 2$ are largely influenced by $\mathrm{Al}$ in the groundwater. The PC2 is a group of the trace elements that may not be sensitive with reduction/oxidation processes. At neutral $\mathrm{pH}$, the predominant form of aluminum is the anion $\mathrm{Al}(\mathrm{OH})_{4}^{-}$. As the oxidation states of $\mathrm{Al}, \mathrm{Ni}, \mathrm{Cd}$, and $\mathrm{Sb}$ do 
not change within the common range of ORP found in natural water, ORP does not significantly affect their solubility unlike Fe, Mn and As (Weiner 2013). Because of similarity in geochemical behavior, $\mathrm{Al}$ and $\mathrm{Ni}$ co-occurred in the groundwater sample ( $r=0.67$, see Table 3$)$. This result agreed with co-occurrence of $\mathrm{Al}$ and $\mathrm{Ni}$ in different types of aquifers in the United States during 1992-2003 (Ayotte et al. 2011).

The PC3 consists of $\mathrm{Pb}, \mathrm{Cu}$ and $\mathrm{Se}$, and explains $15.4 \%$ of the total variance. The PC3 represents trace elements that are immobile in groundwater. Concentrations of $\mathrm{Pb}$, $\mathrm{Cu}$ and $\mathrm{Se}$ were all low. The average concentration of $\mathrm{Pb}$, $\mathrm{Cu}$, and Se were $0.3,3.7$ and $4.7 \mu \mathrm{g} \mathrm{L}^{-1}$, respectively. The low concentrations and relatively unstable characteristics of $\mathrm{Pb}, \mathrm{Cu}$ and $\mathrm{Se}$ are readily explained as a result of their strong sorption on organic and inorganic sediments, clays, minerals, and co-precipitation with other element's oxides (Chang et al. 1984; Weiner 2013). Because of their strong sorption and co-precipitation characteristics, $\mathrm{Pb}, \mathrm{Cu}$ and $\mathrm{Se}$ have longer residence periods in aquifers.

The difference between the $\mathrm{C} 1$ and $\mathrm{C} 2$ aquifers were significant for $\mathrm{Li}, \mathrm{B}, \mathrm{As}, \mathrm{Si}, \mathrm{DO}$ and ORP, but insignificant for $\mathrm{pH}$ and $\mathrm{EC}$. The differences may also be attributed to differences in residence periods between the two aquifers. Overall, the PCA classified the elements into groups representing different hydro-geochemical characteristics in the groundwater.

\section{Hierachical cluster analysis}

The results of HCA for classifying the elements and the aquifers are presented in Fig. 8a, b, respectively. There were three main groups of elements over all the groundwater samples collected during the monitoring period ( $n=154$ ). The first cluster (As, Si, Li, Mn, Fe) and the second cluster $(\mathrm{Ni}, \mathrm{Sb}, \mathrm{Al}, \mathrm{Cd})$ contained the same elements in the PC1 (except B) and in the PC2, respectively. The third cluster $(\mathrm{Cu}, \mathrm{Pb}, \mathrm{Cu}, \mathrm{Se}, \mathrm{Sr}, \mathrm{B})$ contained all the trace elements that are in the PC3. All the elements in the same PC are classified in the same or fairly close clusters in HCA. It confirms the similar properties among the trace elements within the same PC.

HCA for the aquifers and the wells are then presented in Fig. 8b. Most samples collected from the same aquifers or wells are classified into the same or closer clusters. About 77-84\% of the samples collected from the $\mathrm{C} 1$ and $\mathrm{C} 2$ aquifers are classified into the two separated clusters (Fig. 8b). This indicates that there are similarities in trace element distributions among the samples collected from the same aquifer or well and implies that distinct differences in trace element distributions between $\mathrm{C} 1$ and $\mathrm{C} 2$.

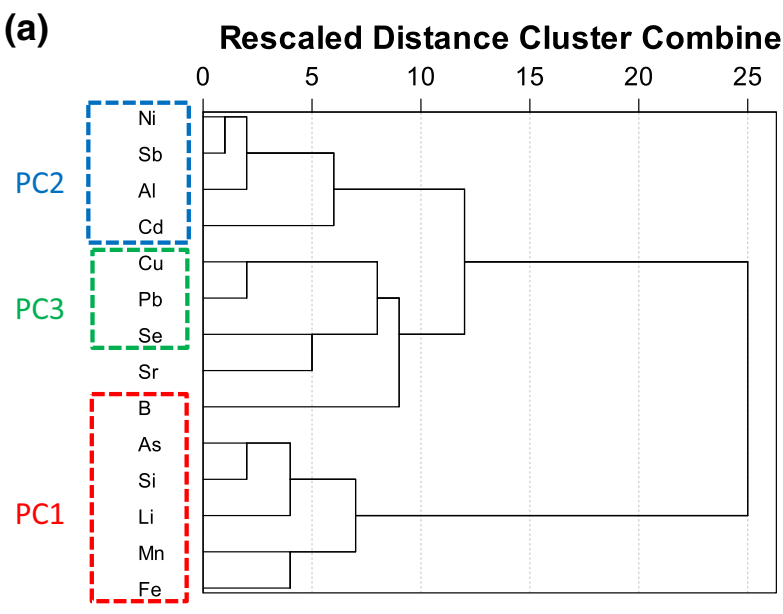

(b)

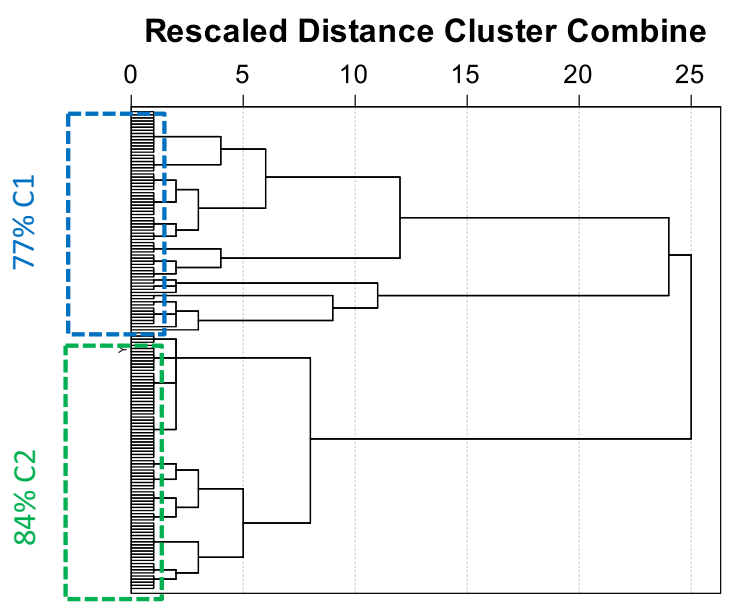

Fig. 8 Dendrogram using Ward Linkage of elements (a), wells and aquifers (b)

\section{Multivariate analysis and its application}

The element concentration variations shown in Fig. 5 highlight the complexity of the element distributions as well as the temporal variations. The multivariate analysis can significantly reduce the number of variables to a few principal components. Because of the multiple dimensionalities in variations, the application of multivariate analysis on element concentrations at each specific time could lead to a failure in recognizing true element groups and/or clusters in the study area. As the multivariate analysis was conducted based on the element concentrations at different times in a year, the characteristics of three identified element groups likely represent the distribution and variation of the elements in the groundwater in the studied area regardless of the time. Particularly, the complexity of the element distributions and variations in the groundwater throughout the year was simplified into three major components as represented by PC1, PC2 and PC3 in 
PCA. HCA confirmed the similarity of the elements in the same principal components. HCA also pointed out the similarity of the elements from the same aquifer and the same well.

\section{Application of GSHP and its potential effects on trace element distribution in groundwater}

Aquifer geochemistry and geological composition of aquifers are the major factors affecting the distributions of trace elements in groundwater. The trace elements in the $\mathrm{C} 1$ and $\mathrm{C} 2$ aquifers are characterized by silt confining layers and by sands and gravels (Fig. 2b). Si, a major chemical component (Fig. 2b), is known as the major element controlling the behavior of other elements in PC1.

The three principal component groups of the elements are very important for assessing changes in groundwater quality due to change in surrounding environment. For examples, intensive use of GSHP may increase groundwater temperatures. Investigation then should focus on changes in $\mathrm{Si}$ and $\mathrm{Al}$ elements since $\mathrm{Si}$ and $\mathrm{Al}$ mainly control the distribution of other trace elements in the study area. If the change in groundwater temperature affects the behavior of Si-minerals, then it alters the dissolution/sorption of other elements from/to local minerals and soils. As $\mathrm{Si}$ is known as a thermal element, higher concentrations of $\mathrm{Si}$ were found in groundwater having higher temperatures (Davis 1964). The activity of GSHP may lead to higher concentrations of $\mathrm{Si}$ and the other trace elements in the PC1. A similar behavior of the elements in PC1 is also expected when GSHP is used in other sand-gravel aquifers. The three principal component groups in this study are possibly useful not only in the assessment of GSHP systems but also any other studies that focus on changes in trace elements in groundwater.

\section{Conclusions}

This study used multivariate statistical techniques to characterize concentrations of 15 elements and standard water quality observed over a year in shallow confined aquifers in Fuchu city, the western suburb of Tokyo Metropolis. All the element concentrations were lower than the environmental quality standard issued by the Japanese Ministry of the Environment. Even though the upper aquifer (C1) and the lower aquifer (C2) had similar groundwater levels, the distributions of some elements were significantly different, probably caused by differences in groundwater residence time.

Time series analysis indicated that there are no clear seasonal trends in element concentrations. Concentrations of $\mathrm{Li}, \mathrm{B}, \mathrm{Fe}, \mathrm{As}, \mathrm{Cd}, \mathrm{Sb}, \mathrm{Pb}$ and $\mathrm{Si}$ are independent of time while concentrations of $\mathrm{Al}, \mathrm{Cr}, \mathrm{Ni}, \mathrm{Cu} \mathrm{Se}$ and $\mathrm{Sr}$ are weakly auto-correlated with a time lag of 2 or 4 weeks which equal to 1-2 sampling-time intervals.

Principal component analyses (PCA) allowed a reduction in the original concentration data matrix into three major PCs (PC1, PC2, and PC3) explaining $61.3 \%$ of the total variance. The PC1 consisted of $\mathrm{Li}, \mathrm{B}, \mathrm{Mn}, \mathrm{Fe}, \mathrm{As}$, and $\mathrm{Si}$, expressing the control of $\mathrm{Si}$ to other trace elements, and representing the mobile trace elements. The PC2 included $\mathrm{Al}, \mathrm{Ni}, \mathrm{Cd}$, and $\mathrm{Sb}$, expressing the dominance of $\mathrm{Al}$ to other trace elements, and representing ORP-insensitive properties. The $\mathrm{PC} 3$ consisted of $\mathrm{Pb}, \mathrm{Cu}$, and $\mathrm{Se}$, representing the immobile trace elements. Two trace elements, $\mathrm{Sr}$ and $\mathrm{Cr}$, were not associated with any principal component and showed lower correlation with other trace elements, thus, they do not represent any major physico-chemical characteristic of groundwater in the study area.

Cluster analyses showed a similarity in elements in groundwater collected from the same aquifer and the same well even though they were collected at different times. The results demonstrated that most groundwater samples collected from the same aquifer and the same well fell into the same or fairly close groups.

Future use of GSHP may alter the distribution of elements in PC1 especially the elements with relatively high loadings such as $\mathrm{Si}$, As and B, thus investigation on the changes in groundwater temperature associated with changes in distributions of these elements are highly recommended.

Acknowledgments This research was supported by Core Research for Evolutionary Science and Technology (CREST) from Japan Science and Technology Agency (JST) and partially supported by Grants-in-Aid for Scientific Research (No. 23380140 and 25292144) from Japan Society for the Promotion of Science (JSPS). The authors are deeply grateful to Mr. Hiromu Muto for collecting groundwater samples from the sampling wells. This paper was written while Dang Quoc Thuyet was a JSPS Postdoctoral Fellow at the Graduate School of Agricultural and Life Sciences, The University of Tokyo.

\section{References}

Akai J, Anawar HM (2013) Mineralogical approach in elucidation of contamination mechanism for toxic trace elements in the environment: Special reference to arsenic contamination in groundwater. Physics Chem Earth Parts A/B/C 58-60:2-12. doi:10.1016/j.pce.2013.04.011

Anawar HM, Akai J, Komaki K, Terao H, Yoshioka T, Ishizuka T, Safiullah S, Kato K (2003) Geochemical occurrence of arsenic in groundwater of Bangladesh: sources and mobilization processes. J Geochem Explor 77:109-131. doi:10.1016/S0375-6742(02) 00273-X

Appelo CAJ, Postma D (2005) Geochemistry, groundwater and pollution. 2 Edn., Taylor \& Francis

Ayotte JD, Gronberg JAM, Apodaca LE (2011) Trace elements and Radon in groundwater across the United States, 1992-2003. In: U.S. Geological Survey Scientific Investigations Report 2011-5059, pp 115 
Chang AC, Warneke JE, Page AL, Lund LJ (1984) Accumulation of heavy metals in sewage sludge-treated soils. J Environ Qual 13:87-91. doi:10.2134/jeq1984.00472425001300010016x

Chen KP, Jiao JJ, Huang JM, Huang RQ (2007) Multivariate statistical evaluation of trace elements in groundwater in a coastal area in Shenzhen. China. Environ Pollut 147:771-780. doi:10.1016/j.envpol.2006.09.002

Cruz JV, Silva MO (2000) Groundwater salinization in Pico Island (Azores, Portugal): origin and mechanisms. Environ Geol 39:1181-1189

Davis SN (1964) Silica in streams and ground water. Am J Sci 262:870-891. doi:10.2475/ajs.262.7.870

Endo T (1992) Confined groundwater system in Tokyo. Environ Geol Water Sci 20:21-34. doi:10.1007/BF01736107

Endo T, Ishii M (1984) Hydrogeology and subjects caused by recovering of groundwater level in Tokyo. J Jpn Soc Eng Geol 25:111-120. doi:10.5110/jjseg.25.111

Farnham IM, Johannesson KH, Singh AK, Hodge VF, Stetzenbach KJ (2003) Factor analytical approaches for evaluating groundwater trace element chemistry data. Anal Chim Acta 490:123-138. doi:10.1016/S0003-2670(03)00350-7

Graves B (1987) Radon in Ground Water. CRC Press (Lewis Publishers)

Hem JD (1989) Study and interpretation of the chemical characteristics of natural water, U.S. Geological Survey, Water Supply Paper 2254. pp 263

Hinton PR (2004) SPSS explained. Routledge

Hogan JF, Blum JD (2003) Boron and lithium isotopes as groundwater tracers: a study at the Fresh Kills Landfill, Staten Island, New York, USA. Appl Geochem 18:615-627. doi:10.1016/ S0883-2927(02)00153-1

Imaizumi M, Komae T, Nihira S (2000) Evaluation of recharge mechanism of confined groundwater using long term tritium concentration records in the Metropolis of Tokyo. J Jpn Soc Eng Geol 41:87-102

JMOE (2003) Environmental Quality Standards for Groundwater Pollution. Ministry of the Environment Government of Japan (JMOE)

Jolliffe IT (2002) Principal component analysis. Springer

Kim J-H, Kim R-H, Lee J, Cheong T-J, Yum B-W, Chang H-W (2005) Multivariate statistical analysis to identify the major factors governing groundwater quality in the coastal area of Kimje, South Korea. HyPr 19:1261-1276. doi:10.1002/hyp.5565

Komatsu T (2012) Thermal disturbances in the subsurface environment and groundwater conservation. In: JSPS Workshop on Water and Urban Environment, pp 1-40

Koonce JE, Yu Z, Farnham IM, Stetzenbach KJ (2006) Geochemical interpretation of groundwater flow in the southern Great Basin. Geosphere 2:88-101. doi:10.1130/Ges00031.1

Kuroda K, Fukushi T (2008) Groundwater contamination in urban areas. In: Takizawa $S$ (ed) Groundwater management in Asian Cities. Springer, Japan, pp 125-149

Kuroda K, Murakami M, Oguma K, Muramatsu Y, Takada H, Takizawa S (2011) Assessment of groundwater pollution in Tokyo using PPCPs as sewage markers. Environ Sci Technol 46:1455-1464. doi:10.1021/es202059g

Langmuir D (1997) Aqueous environmental geochemistry. Prentice Hall

Lee J, Ko K-S, Kim J-M, Chang H-W (2008) Multivariate statistical analysis of underground gas storage caverns on groundwater chemistry in Korea. HyPr 22:3410-3417. doi:10.1002/hyp. 6921

Luu TTG, Sthiannopkao S, Kim K-W (2009) Arsenic and other trace elements contamination in groundwater and a risk assessment study for the residents in the Kandal Province of Cambodia. Environ Int 35:455-460. doi:10.1016/j.envint.2008.07.013

Mason RP (2013) Trace metals in aquatic systems. Wiley-Blackwell

Murakami M, Kuroda K, Sato N, Fukushi T, Takizawa S, Takada H (2009) Groundwater pollution by perfluorinated surfactants in Tokyo. Environ Sci Technol 43:3480-3486. doi:10.1021/ es803556w

Négrel P, Millot R, Brenot A, Bertin C (2010) Lithium isotopes as tracers of groundwater circulation in a peat land. Chem Geol 276:119-127. doi:10.1016/j.chemgeo.2010.06.008

Nga T (2008) Arsenic contamination in Hanoi City, Vietnam. In: Groundwater Management in Asian Cities, Takizawa S (ed.) Springer Japan, pp 273-299

Phan K, Phan S, Huoy L, Suy B, Wong MH, Hashim JH, Mohamed Yasin MS, Aljunid SM, Sthiannopkao S, Kim K-W (2013) Assessing mixed trace elements in groundwater and their health risk of residents living in the Mekong River basin of Cambodia. Environ Pollut 182:111-119. doi:10.1016/j.envpol.2013.07.002

Ramesh R (1999) Groundwater quality management: polution perspectives. In: Ellis JB (ed) Impacts of urban growth on surface water and groundwater quality. IAHS publication, pp 47-55

Saito T, Hamamoto S, Mon EE, Takemura T, Saito H, Komatsu T, Moldrup P (2014) Thermal properties of boring core samples from the Kanto area, Japan: Development of predictive models for thermal conductivity and diffusivity. Soils Found 54:116-125. doi:10.1016/j.sandf.2014.02.004

Shand P, Edmunds WM (2008) The baseline inorganic chemistry of European groundwater. In: Edmunds WM, Shand P (eds) Natural groundwater quality. Blackwell Publishing, pp: 22-58

Shyu GS, Cheng BY, Chiang CT, Yao PH, Chang TK (2011) Applying factor analysis combined with kriging and information entropy theory for mapping and evaluating the stability of groundwater quality variation in Taiwan. Int $\mathrm{J}$ Environ Res Public Health 8:1084-1109. doi:10.3390/ijerph8041084

Stetzenbach KJ, Farnham IM, Hodge VF, Johannesson KH (1999) Using multivariate statistical analysis of groundwater major cation and trace element concentrations to evaluate groundwater flow in a regional aquifer. HyPr 13:2655-2673. doi:10.1002/ (SICI)1099-1085(19991215)13:17<2655:AID-HYP840>3.0.CO; 2-4

Takei K (1975) On the pebbles of Igneous Rocks, Metamorphic Rocks and Acidic Tuffs in the Cretaceous Conglomerate of the Sanchu Graben, Kanto Mountains. J Geol Soc Jpn 81:247-254

Tanji K, Valoppi L (1989) Groundwater contamination by trace elements. Agric. Ecosyst Environ 26:229-274. doi:10.1016/ 0167-8809(89)90015-7

Ward JH (1963) Hierarchical grouping to optimize an objective function. J Am Stat Assoc 58:236-244. doi:10.1080/01621459. 1963.10500845

Weiner ER (2013) Applications of environmental aquatic chemistry : A practical guide. CRC Press/Taylor \& Francis Group

White DE, Hem JD, Waring GA (1963) Chemical composition of subsurface waters. In: Data of Geochemistry, Sixth edn, p 67

WHO (2011) Guidelines for drinking-water quality, fourth edition. World Health Organization

Wilson N (1995) Soil Water and Ground Water Sampling. CRC Press

Wold S, Esbensen K, Geladi P (1987) Principal component analysis. Chemom Intell Lab Syst 2:37-52. doi:10.1016/01697439(87)80084-9 